\title{
Evidence for the Existence of Globular Units in the Supranucleosomal Organization of Chromatin
}

\author{
H. ZentgraF ${ }^{1}$, U. MÜller ${ }^{2}$, U. ScheER ${ }^{2}$, and W. W. Franke ${ }^{2}$
}

One of the significant steps in the past decade of chromatin research has been the finding of the nucleosome as the common principle form of DNA-histone organization (Hewish and Burgoyne 1973; Kornberg 1974; Olins and Olins 1974; for review see Chambon 1978). In most eukaryotic nuclei the bulk of the chromatin is associated with histones in a regular pattern and is organized, in the non-transcribed chromatin regions, in nucleosomal particles, which can be visualized by electron microscopy of spread chromatin in extended nucleosomal filaments, i.e. 10-12 nm large beads-on-a-string (Fig. $1 \mathrm{a}$ ). This principle of packing in globular repeating units results in an overall foreshortening of the DNA by a factor of 5-6. However, some other forms of DNA arrangement in chromatin have also been reported: (i) the dinoflagellate chromosome (for references see Rae and Steele 1978); (ii) DNA newly replicated in the absence of protein synthesis (Riley and Weintraub 1979); (iii) actively transcribed chromatin in which the nucleohistone is organized in such a way that the contained DNA is in a predominantly extended configuration (Fig. 1 b; Foe et al. 1976; Foe 1978; Franke et al. 1976, 1978; Reeder et al. 1978; Trendelenburg et al. 1976; for references see Franke et al. 1979); and (iv) chromatin present in cells infected with adenovirus (Kedinger et al. 1978; Matsuguchi et al. 1979; Miller and Hodge 1975) and herpes simplex virus (Müller et al. 1980): In the case of herpes-infected cells, a total of four different forms of chromatin are observed (Fig. 1 c).

\footnotetext{
${ }^{1}$ Institute of Virus Research and ${ }^{2}$ Division of Membrane Biology and Biochemistry, Institute of Cell and Tumor Biology, German Cancer Research Center, D-6900 Heidelberg 1, FRG
}

However, the reports of all these different types of nucleosomal and non-nucleosomal chromatin configurations are almost exclusively based on studies of chromatin dispersed in solutions containing very low salt concentrations. It is obvious that extended nucleosomal filaments as shown in Fig. 1 a do not occur in the living cell nucleus since the ion concentrations determined in nuclei of living cells (Century et al. 1970; Century and Horowitz 1974; Dick and Fry 1973; Paine et al. 1975; Riemann et al. 1969) favor the arrangement of nucleosomes into higher order structures. The important question therefore is: What is the organization of the chromatin in the nucleus of the living cell?

It has been long known that transcriptionally inactive chromatin is condensed and appears, in electron micrographs of ultrathin sections through fixed cells, in the form of densely stained $20-50 \mathrm{~nm}$ thread-like units, often with a periodic granular substructure. Such arrays of dense chromatin are often especially conspicuous along the inner nuclear membrane (e.g., Fig. 6 a; for references see Franke and Scheer 1974; Franke et al. 1978; Zentgraf et al. $1980 \mathrm{a}, \mathrm{b}$ ). Discussions on the higher order organization of chromatin can start from the general consensus that transcriptionally inactive chromatin appears in fibrillar arrays of diameters $20-50 \mathrm{~nm}$ but the interpretation of the arrangement of the nucleosomal chain within this higher order fibril is highly controversial. In particular, there is continuing debate whether the thick fibril seen in sections is continuous and homogeneous (Davies et al. 1974; Davies and Haynes 1976; Everid et al. 1970), or is composed of tightly apposed globular subunits of the diameter of the fiber (Franke and Scheer 1974; Franke et al. 1978; Zentgraf et al. 

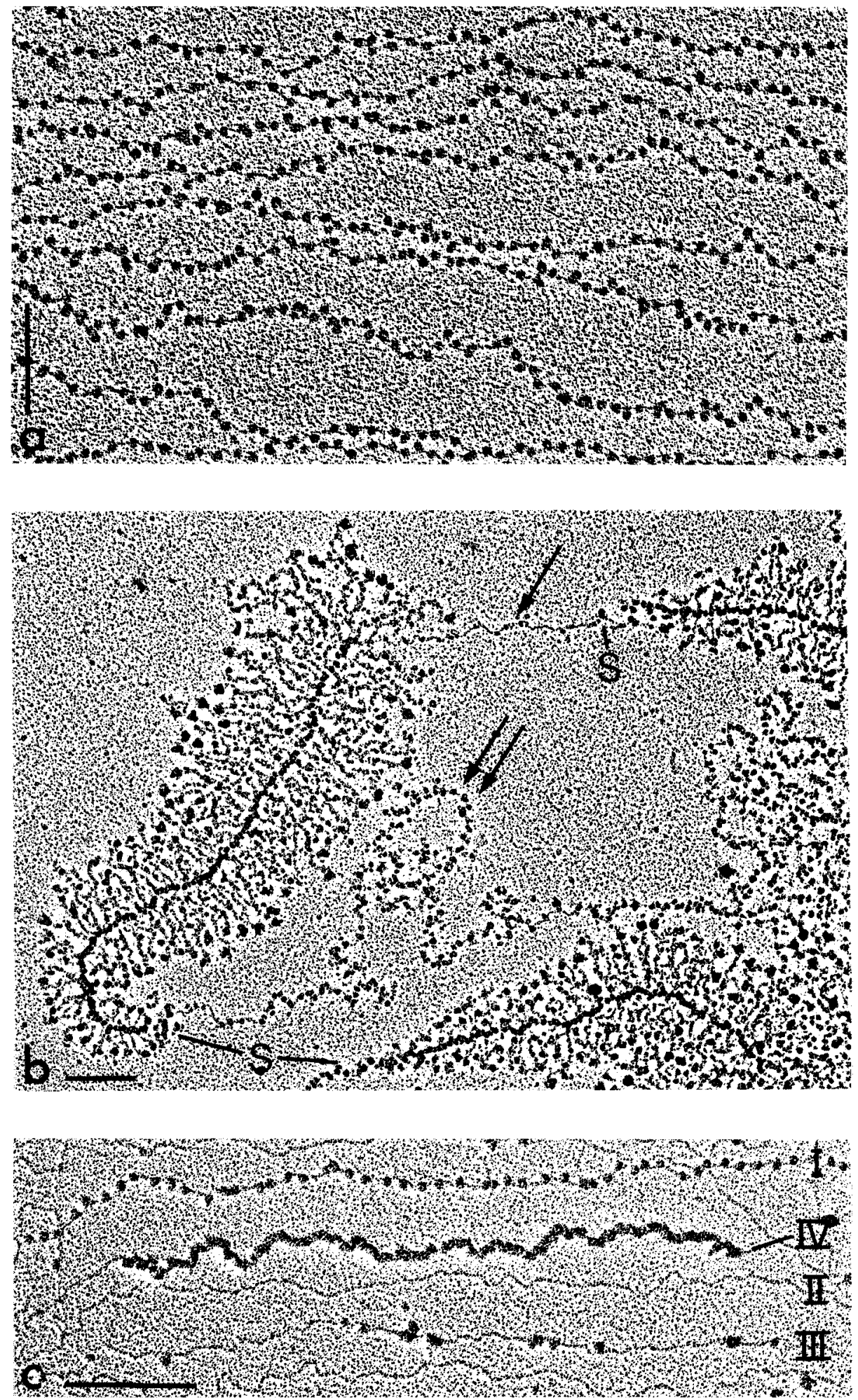
1975; Zentgraf et al. 1980 a, b). Recently two extreme concepts on the in vivo packing of the nucleosomal filament in the higher order fibril have been proposed: On one hand, supercoiled or solenoidal arrangements of the nucleosomal chain into a continuous, uniformly thick $25 \mathrm{~nm}$ fiber has been suggested (Finch and Klug 1976; Thoma et al. 1979; Worcel 1980); on the other hand, the chromatin fibril has been interpreted as an array of closely packed higher order granules of different dimensions $(20-50 \mathrm{~nm})$ and nucleosome contents, possibly characteristic of the specific type of chromatin (for references see Table 1). In the following several lines of experimental observations will be presented which support the concept that nucleosomal chains are arranged in granular particles of diameters about two or three times the size of the nucleosome.

The first indication for the existence of granular forms of higher order packing of nucleosomal chains has come from studies on the small chromatin circles ("minichromosomes") of intracellular forms of simian virus 40 (SV40). When prepared under physiological salt conditions, the SV 40 chromatin is arranged in granular particles of about $30 \mathrm{~nm}$ (Fig. $2 \mathrm{a}$ ) which, upon exposure to low salt concentrations, can be unravelled into nucleosome-containing circles (Fig. 2 b; Griffith 1975; Griffith and Christiansen 1978; Keller et al. 1978; Müller et al. 1978; Zentgraf et al. 1978; see there for further references). Assembly of circular DNA molecules into nucleosomes and supranucleosomal chromatin structures is not restricted to viral chromatin. In oocytes of several organisms such as the water beetle, Dytiscus marginalis, and the house cricket, Acheta domesticus, large amounts of amplified ribosomal DNA occur in rings containing one, two or more ribosomal RNA genes (Gall and Rochaix 1974; Trendelenburg 1974; Trendelenburg et al. 1976). When these circles of rRNA genes are not transcribed as, e.g., in the nucleolar chromatin of previtellogenic oocytes, they show, upon prolonged exposure to low salt buffer, the characteristic beaded string configuration indicative of nucleosomal packing (Fig. 2c; Scheer and Zentgraf 1978). In addition, such inactive chromatin circles often appear to be compacted into globular higher order structures of diameters $21-34 \mathrm{~nm}$, suggesting that each higher order granule is an aggregate of 6-9 nucleosomes (Insert in Fig. 2c; Scheer and Zentgraf 1978).

The assembly of circular DNA into chains of nucleosomal particles, and subsequently, into higher order granules can be studied experimentally. When circular DNA molecules are injected into amphibian oocyte nuclei they are assembled into chromatin-like configurations showing typical nucleosomal morphology (Wyllie et al. 1978; Zentgraf et al. 1979). After brief dispersal in low salt buffer or after incubation once at maintained physiological ionic strength, it was demonstrated that the injected DNA molecules are assem-

Fig. 1. Appearance of nucleosomal (a, and type $I$ in c) and non-nucleosomal chromatin configurations (b, and types II, III in $\mathbf{c}$ ) in spread preparations of nuclei of eucaryotic cells. Typical transcriptionally inactive nucleosomal chromatin from chicken erythrocyte is shown in a (for details see Zentgraf et al. $1980 \mathrm{~b}$ ). In the typical transcribed nucleolar chromatin (from oocytes of the frog, Rana pipiens, shown in $\mathbf{b}$; for details see Trendelenburg and McKinnel 1979), transcribed chromatin segments are densely packed with polymerases and nascent ribonucleoprotein fibrils ( $S$ denotes start of matrix unit). Some spacers between transcriptional units are in a thin and smooth (non-beaded) configuration (arrow), whereas other nontranscribed regions (double-arrow) show a beaded nucleosome-like appearance, typical of inactive nucleolar chromatin. Besides chromatin strands with nucleosomal organization (type I in c), spread preparations of chromatin from Herpes virus (HSV)-infected green monkey kidney cells grown in culture also reveal other forms of chromatin such as thin $(3-5 \mathrm{~nm})$ strands indistinguishable from free DNA (type II), thin strands with some attached $10-22 \mathrm{~nm}$ granules of non-nucleosomal nature (type III), and an unusual type of thickly coated strands (type IV; for details see Müller et al. 1980). Bars $0.2 \mu \mathrm{m}$. a 82,000×. b $54,000 \times$. c $94,000 \times$ 

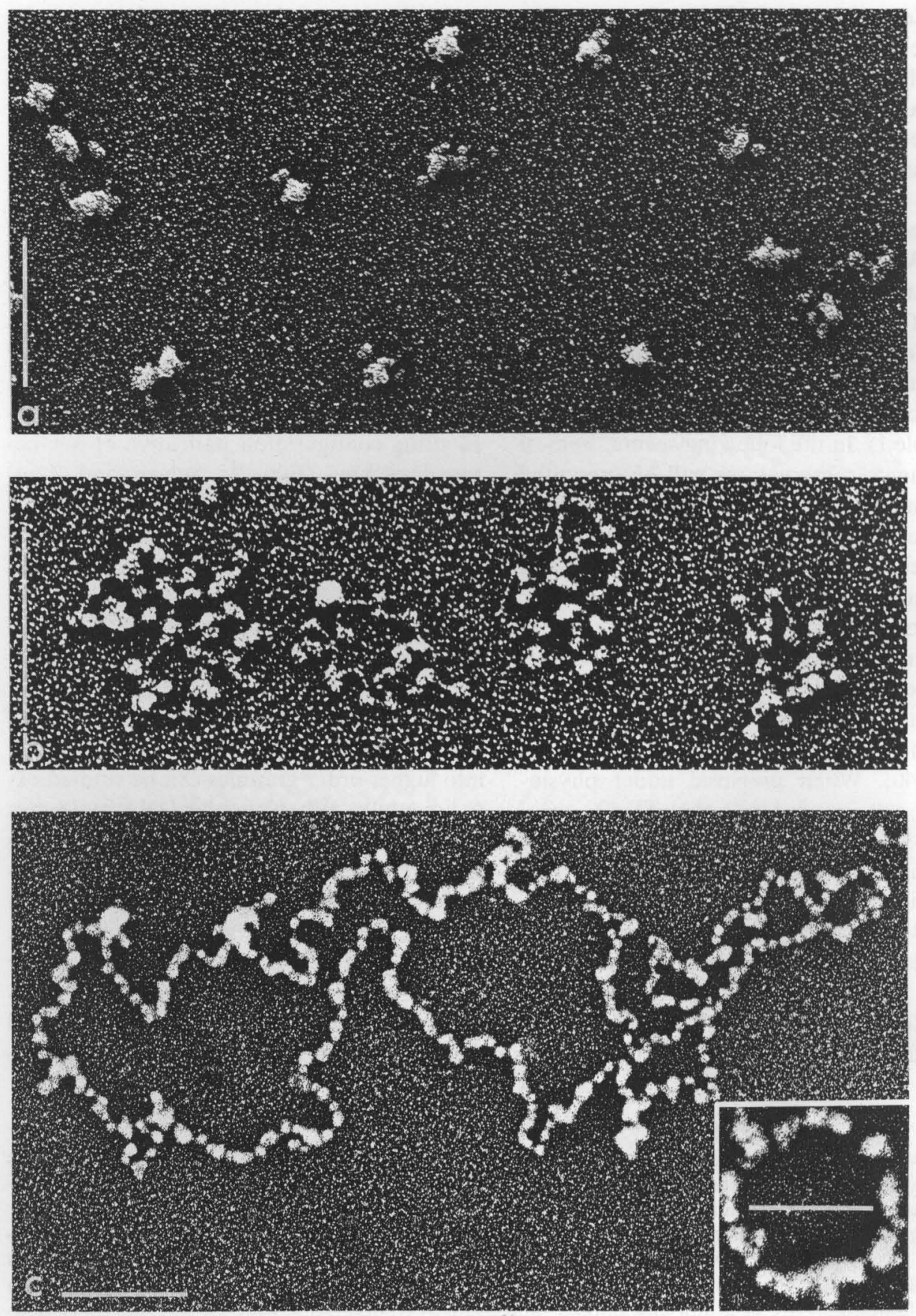

Fig. 2. Condensed chromatin of simian virus 40 arranged in granular $30 \mathrm{~nm}$ large particles (a), which can be unravelled into nucleosomes upon exposure to low salt concentrations (b). Beaded aspect indicative of nucleosomal arrangement is also observed in the transcriptionally inactive rDNA chromatin circles of previtellogenic oocytes of the water beetle, Dytiscus marginalis (c), which also can form $20-35 \mathrm{~nm}$ large supranucleosomal granules (Insert in Fig. 2c; for details see Scheer and Zentgraf 1978). Bars $0.2 \mu \mathrm{m}$. a $106,000 \times$. b $128,000 \times$.c $86,000 \times$. Insert in c $84,000 \times$ 
Table 1

\begin{tabular}{|c|c|c|c|}
\hline Reference & Material & Methods & Conclusion \\
\hline $\begin{array}{l}\text { Franke et al. } \\
1976\end{array}$ & $\begin{array}{l}\text { Chicken erythro- } \\
\text { cytes, isolated nu- } \\
\text { clei from rat liver } \\
\text { and cultured cells }\end{array}$ & $\begin{array}{l}\text { Brief dispersion in } \\
\text { low salt buffers, } \\
\text { spread preparations }\end{array}$ & $\begin{array}{l}\text { ". . these larger chromatin glob- } \\
\text { ules ( } 26 \mathrm{~nm} \text { ) represent further con- } \\
\text { densation and packing of the nu- } \\
\text { cleosomal bead chains, character- } \\
\text { istic for certain topological classes } \\
\text { of inactive chromatin..." }\end{array}$ \\
\hline $\begin{array}{l}\text { Kiryanov et al. } \\
1976\end{array}$ & $\begin{array}{l}\text { Isolated rat liver } \\
\text { nuclei and chroma- } \\
\text { tin fractions }\end{array}$ & $\begin{array}{l}\text { Ultrathin sections } \\
\text { and spread prepara- } \\
\text { tions; emphasis on in- } \\
\text { fluence of } \mathrm{Mg}^{2+} \text { and } \\
\text { EDTA }\end{array}$ & $\begin{array}{l}\text { "The basic structural unit of chro- } \\
\text { matin is a } 200 \AA \text { DNP fibril con- } \\
\text { sisting of stacked globules of the } \\
\text { diameter }(200 \AA) . "\end{array}$ \\
\hline $\begin{array}{l}\text { Renz et al. } \\
1977\end{array}$ & $\begin{array}{l}\text { Chromatin from bo- } \\
\text { vine lymphocyte } \\
\text { nuclei, including mi- } \\
\text { croccocal nuclease- }\end{array}$ & $\begin{array}{l}\text { Sedimentation in su- } \\
\text { crose gradients, } \\
\text { spread preparations; } \\
\text { emphasis on involve- }\end{array}$ & $\begin{array}{l}\text { ". . chromosome fibers are } 200 \AA \\
\text { in diameter and composed of dis- } \\
\text { crete globular structures." }\end{array}$ \\
\hline $\begin{array}{l}\text { Hozier et al. } \\
1977\end{array}$ & $\begin{array}{l}\text { digested chromatin } \\
\text { fractions }\end{array}$ & ment of histone $\mathrm{Hl}$ & $\begin{array}{l}\text { "Individual knobs ("superbeads") } \\
\text { are arranged in tandem and have } \\
\text { an average diameter of about } \\
200 \AA . "\end{array}$ \\
\hline
\end{tabular}

bled not only into nucleosomes, at the first level, but also into supranucleosomal granules of about $30 \mathrm{~nm}$ diameter of higher order organization. A similar transformation of circular molecules into granular higher order chromatin structures is also observed after incubation with the proteins present in $100,000 \times \mathrm{g}$ supernatants of homogenized amphibian oocyte nuclei and then centrifuged in discontinuous sucrose gradients containing $100 \mathrm{mM}$ salt (Fig. 3; for details see Scheer et al. 1980). Under such conditions it was estimated that the DNA molecules are compacted in a way resulting in an overall foreshortening by a factor of $30-50$.

The concept of a supranucleosomal organization of chromatin in regularly arranged granular units has also received support from experiments using rat liver chromatin after limited digestion with micrococcal nuclease. In such experiments it was demonstrated that the nucleosomal chromatin is present in large granules which can be prepared in the form of monomeric $(23 \mathrm{~nm})$ and dimeric $(29 \mathrm{~nm})$ spheroidal particles, each containing a mean of eight nucleosomes (Strätling et al.
1978). This essentially confirms the results of Renz and colleagues (Hozier et al. 1977; Renz et al. 1977) who have shown that the $200 \AA$ chromatin fiber is composed of tandemly arranged, discrete globular $20 \mathrm{~nm}$ structures.

However, such demonstrations of granular chromatin aggregates of nucleosomes ("superbeads"; Hozier et al. 1977; Renz et al. 1977) in relatively short oligonucleosomal fragments is open to the criticism that these structures result from artificial collapse and aggregation. Therefore, we decided to use non-fragmented chromatin of whole nuclei to examine the gradual, salt-dependent transition from native chromatin structure to extended nucleosomal chains, and vice versa. When isolated nuclei from a diversity of animal and plant cells (e.g. HeLa cells, Fig. 4 a; corn root tip cells, Fig. 4b) are lysed and briefly incubated in low salt buffer, the partly dispersed chromatin appears in characteristic granules of diameters $25-35 \mathrm{~nm}$, which are often closely packed and serially arranged into thick "discontinuous" fibrils (Fig. $4 \mathrm{a}, \mathrm{b}$; for details see Zentgraf et al. $1980 \mathrm{a}$, 

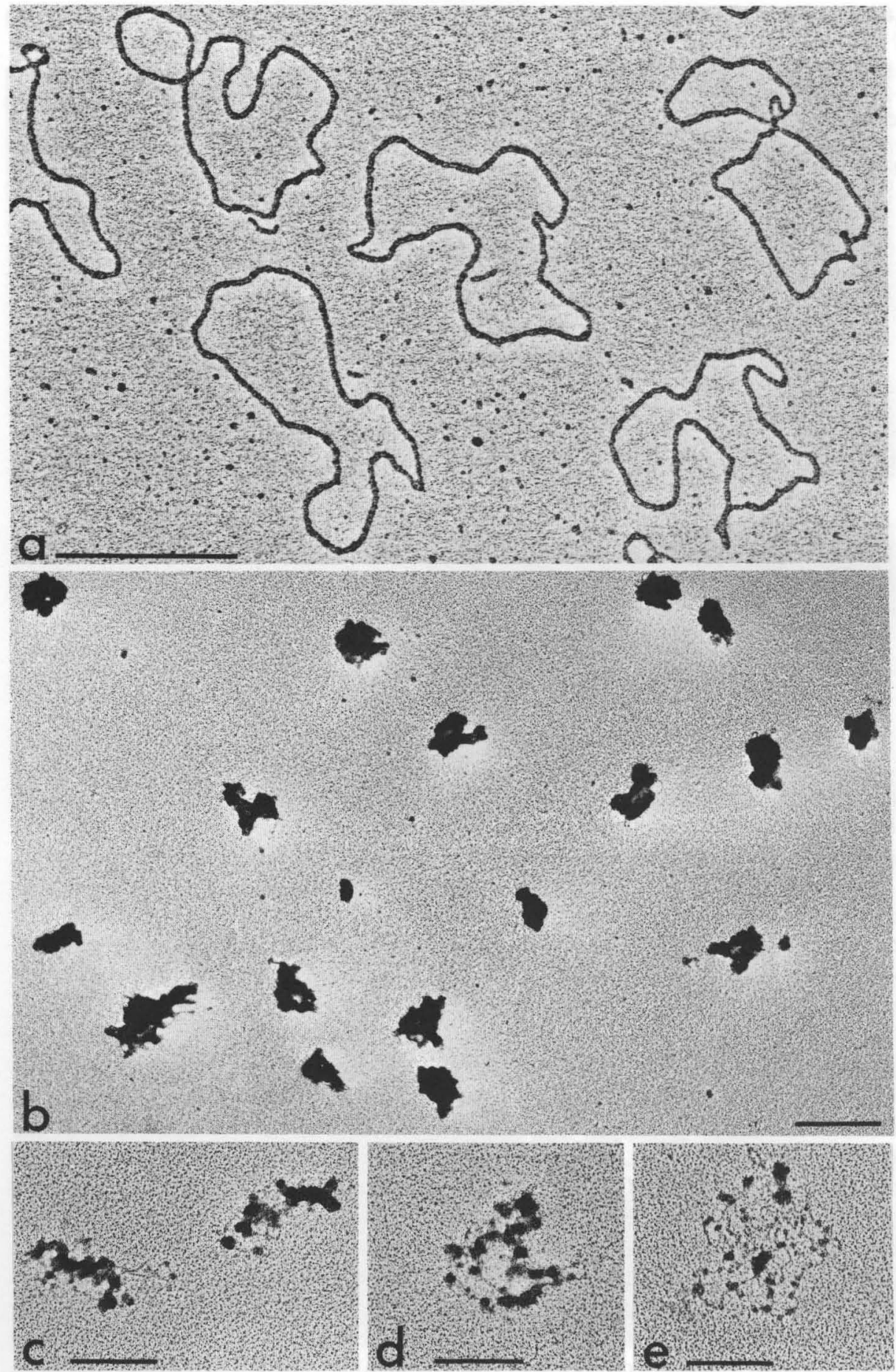

Fig. 3. Packing of circular DNA (plasmid PTP 6AAl shown in a with cytochrome-c spreading) during incubation with proteins present in a $100,000 \times \mathrm{g}$ supernatant fraction from nuclei of oocytes of Pleurodeles walt lii and subsequent purification by sucrose gradient centrifugation (for details see Scheer et al. 1980). The newly assembled plasmid chromatin appears at physiological salt concentrations in the form of large granular particles (b), which, at low salt concentrations, are unravelled into chains of nucleosome-like structures $(\mathbf{c}-\mathbf{e})$. Bars $0.5 \mu \mathrm{m}(\mathbf{a}), 0.2 \mu \mathrm{m}(\mathbf{b}-\mathbf{e})$. a $50,500 \times$. b $61,000 \times$. c $61,000 \times$. d $61,000 \times$. e 61,000× 

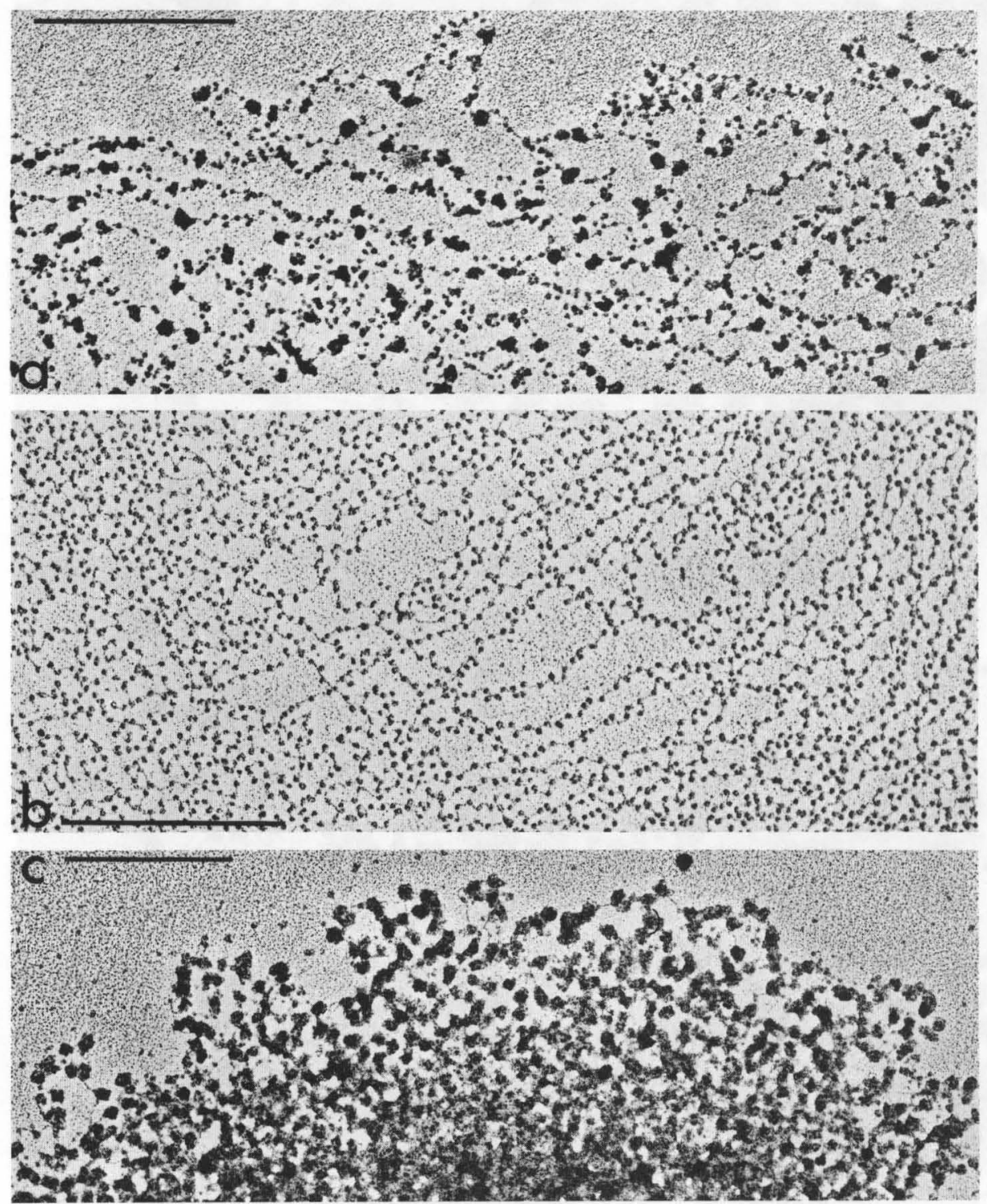

Fig. 5. Chicken erythrocyte chromatin briefly lysed in low salt buffer reveals $18-30 \mathrm{~nm}$ higher order granules inter-connected by strand regions of nucleosomal filaments (a) as typical of intermediate stages of unravelling of native condensed chromatin into nucleosomal chains. Maximally extended nucleosomal filament chromatin as obtained after prolonged treatment with low salt buffer (b) is rapidly recondensed in vitro after dialysis against buffers containing physiological salt concentrations and shows similar chains of serially arranged supranucleosomal granules as the native chromatin (c; for details see Zentgraf et al. 1980 b). Bars $0.5 \mu \mathrm{m}$. a $51,000 \times$.b $58,000 \times . \mathbf{c} 42,000 \times$ 
b). Upon prolonged incubation in low salt buffer, the supranucleosomal granular structures are progressively lost and the material is completely unravelled into the extended nucleosomal chains characteristic of maximally dispersed chromatin (shown in Fig. $4 \mathrm{c}$ for the chromatin of Zea mays).

One of the classic objects of chromatin research is the chicken erythrocyte nucleus, which is characterized by the high degree of homogeneity of its inactive and highly condensed chromatin. Examination of spread preparations of minimally dispersed chick erythrocyte chromatin, such as present after short times of incubation in low salt buffer, reveal the presence of large $(18-30 \mathrm{~nm})$ chromatin granules interspersed between regions of extended nucleosomal filaments (Fig. 5 a). The observation of large chromatin granules, of globular structures of intermediate sizes and shapes on the same nucleosomal filament, and the progressive unravelling of this chromatin into extended nucleosomal chains in low salt suggests that the rows of large (20-30 nm) granules represent the native state of higher order packing of the nucleosomal chain (Franke et al. 1976; Zentgraf et al. $1980 \mathrm{~b}$; see also Pruitt and Grainger 1980). When such avian erythrocyte chromatin present as extended nucleosomal filaments (Fig. 5 b) is dialyzed against buffers of elevated salt concentrations (e.g., containing $100 \mathrm{mM} \mathrm{NaCl}$ ) or, alternatively, nano- to millimolar concentrations of magnesium salts (Zentgraf et al. 1980 b), it rapidly and almost completely recondenses into arrays of higher order beads of similar sizes as those observed in native chromatin (Fig. $5 \mathrm{c}$; for details on in vitro recondensation see Zentgraf et al. 1980 b). This recondensation of nucleosomal chains into chains of supranucleosomal granules is highly reversible as shown upon exposure to buffers containing low salt concentrations, which again results in complete unravelling into nucleosomal chains (Fig. 5 b). These different states of chromatin configuration, (i) the native higher order particles, (ii) the extended nucleosomal chains, and (iii) the experi- mentally recondensed higher order form can also be demonstrated in ultrathin sections (Fig. 6). When chromatin dispersed in solutions containing low salt concentrations is fixed in aldehyde solutions maintaining low salt concentration (see Olins et al. 1980; Zentgraf et al. $1980 \mathrm{~b}$ ), it appears in the form of typical beaded nucleosomal filaments often revealing the characteristic "zig-zag arrays" (Fig. 6 b). When such maximally extended chromatin is allowed, by exposure to physiological salt concentrations, to recondense and is fixed with glutaraldehyde in the presence of, e. g., $100 \mathrm{mM} \mathrm{NaCl}$, it again appears in $20-30 \mathrm{~nm}$ large, more or less closely spaced, beads, which is particularly clearly seen where it is in close contact with fragments of the nuclear envelope (Fig. 6c).

An extreme example of uniformly structured, highly condensed chromatin is present in sea urchin sperm. In this cell the chromatin reveals, in ultrathin sections, dense circular profiles $(31-40 \mathrm{~nm})$ that seem to be closely packed into fibrils with a discrete indicated subunit pattern (not shown here; for details see Zentgraf et al. 1980a). When briefly lysed in low salt buffers, this chromatin displays a relatively homogeneous composition of uniformly sized $(47 \mathrm{~nm})$, large supranucleosomal granules separated by short strands of nucleosomes (Fig. 7a). Upon prolonged incubation in solutions of low salt concentrations, the chromatin strands, which are often arranged in loops, show an increased number of nucleosomes located between residual, large supranucleosomal granules (Fig. 7 b). This and the increasing number of intermediate-sized granular structures of irregular sizes and shapes suggest a progressive unravelling of the higher order chromatin beads (estimated contents of 20-26 nucleosomes) into the extended nucleosomal chains (Fig. $7 \mathrm{c}$ ). Whether the formation of the extremely large supranucleosomal beads in the sea urchin sperm chromatin is related to the presence of special forms of histones $\mathrm{H} 2 \mathrm{~A}$, H2B, and $\mathrm{Hl}$ (Wangh et al. 1972) and/or to the unusually high nucleosomal repeat length of 240 nucleotides of DNA (Spadafo- 

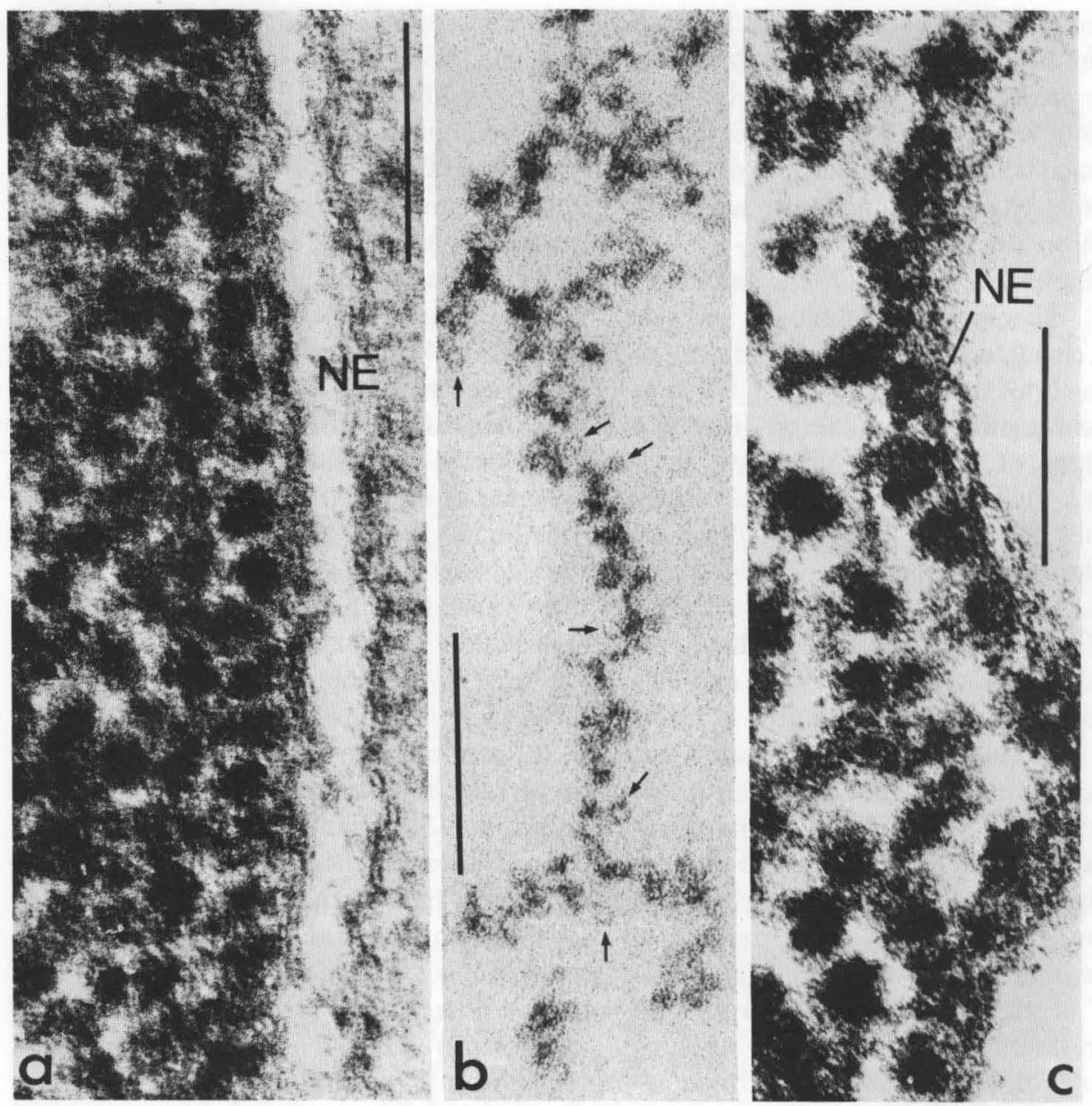

Fig. 6. Electron micrographs of ultrathin sections of chicken erythrocyte chromatin present in intact cells (a), dispersed in low salt buffer (b) and after recondensation in vitro into higher order form (c). Dispersed chromatin showing extended nucleosomal filaments (arrows in b, denote some nucleosomes revealing a relatively unstained core) is recondensed at elevated ion concentrations into relatively closely packed, 20-30 nm large granules, which sometimes are intimately associated with remnants of the nuclear envelope $(N E)$, thus resembling the aspect of the outermost layer of the condensed chromatin observed in intact erythrocyte nuclei (a; for details on fixation procedures see Zentgraf et al. 1980 b). Bars $0.1 \mu \mathrm{m}$. a $270,000 \times$. b $270,000 \times$. c $270,000 \times$

ra et al. 1976) remains to be examined. Likewise the correlation of higher order chromatin structure (for reports of differences of nucleosomes per supranucleosomal bead see also Meyer and Renz 1979) to specific histone composition and nucleosomal DNA repeat length (for avian erythrocytes see Morris 1976, and Chambon 1978) is not clear at the moment.
In discussing the significance of the granular forms of higher order organization of the nucleosomal filament, it is worth emphasizing that the supranucleosomal granules described above are seen when possible preparation artifacts are minimized, for example by the use of unsheared long chromatin strands freshly prepared by brief lysis of isolated nuclei (see also Kiryanov et al. 1976) or 

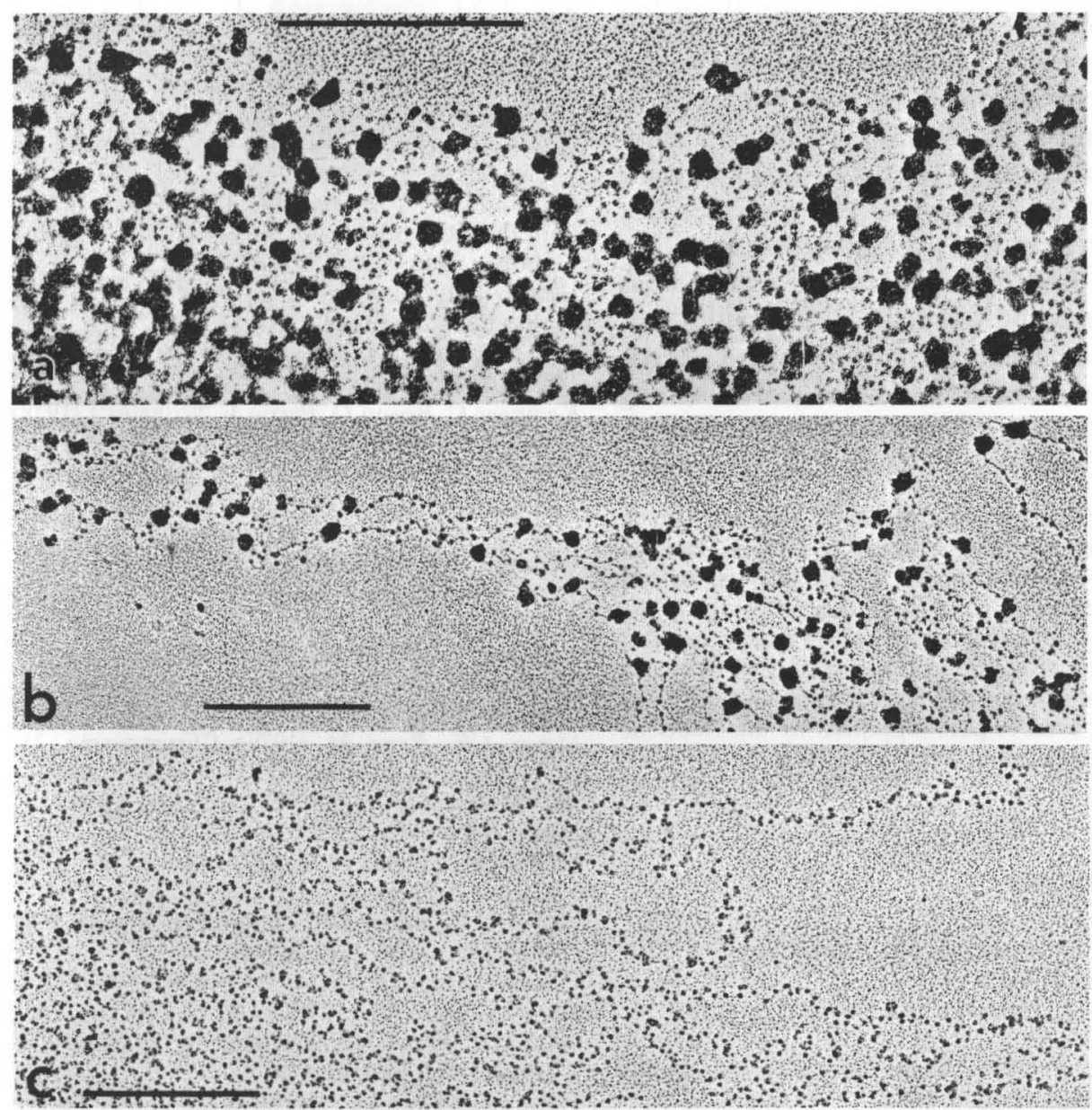

Fig. 7. Sea urchin sperm chromatin, briefly lysed in low salt buffer, is mostly contained in large, uniformly sized $(40-50 \mathrm{~nm})$ supranucleosomal granules that in some regions, especially in the periphery, are interconnected by short intercepts of extended nucleosomal filament morphology (a). Upon further incubation in low salt concentrations the number of large supranucleosomal granules is decreased and the proportion of extended nucleosomal filaments increased suggesting progressive unravelling into the extended nucleosomal chains (b). The final state as obtained after prolonged incubation at very low ionic strength is shown in $\mathbf{c}$ and presents a uniform appearance of the chromatin in extended nucleosomal filaments. Bars $0.5 \mu \mathrm{m}$. a $58,000 \times$. b 38,000 . c $39,000 \times$

intact cells. Relatively short (up to about $0.5 \mu \mathrm{m}$ ) regions of solenoid-like configuration or forms of other more tightly, closepacked, 20-30 nm chromatin fibrils (including structures described by Olins and Olins 1979; Rattner and Hamkalo 1979; Worcel 1978) have been occasionally seen in our systematic studies on progressive chromatin dispersal in solutions of lowered salt concen- trations (for an example see Zentgraf et al. $1980 \mathrm{~b}$ ), indicating that such configurations are intermediates of chromatin swelling rather than native structures formed in the physiological ion environment of the living cell nucleus.

The chemical principle, that gives rise to the formation of these specific supranucleosomal arrangements in chromatin are not under- 
stood. While a general involvement of histone $\mathrm{H} 1$ and $\mathrm{H} 5$ in the condensation of the nucleosome filament into higher order fibrils and granules has been indicated by a number of experiments (Keller et al. 1978; Renz et al. 1977; Thoma et al. 1979; see there for further references), the specific role and location of these histones in the higher order structure is still unknown. It is obvious that specific biochemical and topological experiments are needed for further understanding of the packing of chromatin at the supranucleosomal level.

Acknowledgements. We thank M. Schrenk and S. Mähler for excellent technical assistance, Drs. M. F. Trendelenburg and W. Keller (this center), A. Olins and D. Olins and T. Martin (all guests of the German Cancer Research Center during summer 1980) for helpful discussion, as well as M. Williams for reading and correcting the manuscript. This work has been in part supported by the Deutsche Forschungsgemeinschaft.

\section{References}

Century TJ, Fenichel JR, Horowitz SB (1970) J Cell Sci 7:5-13

Century TJ, Horowitz SB (1974) J Cell Sci 16: 465-471

Chambon P (1978) Cold Spring Harbor Symp Quant Biol 42: 1209-1234

Davies HG, Haynes ME (1976) J Cell Sci 21: 315-327

Davies HG, Murray AB, Walmsley ME (1974) J Cell Sci 16:261-299

Dick DAT, Fry DJ (1973) J Physiol (Lond) 231: 19-29

Everid AC, Small JV, Davies HG (1970) J Cell Sci $7: 35-48$

Finch JT, Klug A (1976) Proc Natl Acad Sci USA 73: $1897-1901$

Foe VE (1978) Cold Spring Harbor Symp Quant Biol 42: 723-740

Foe VE, Wilkinson LE, Laird CD (1976) Cell 9: 131-146

Franke WW, Scheer U (1974) In: Busch H (ed) The cell nucleus, vol l. Academic Press, New York San Francisco London, p 219-347

Franke WW, Scheer U, Trendelenburg MF, Spring H, Zentgraf H (1976) Cytobiologie 13:401-423

Franke WW, Scheer U, Trendelenburg MF, Zentgraf H, Spring H (1978) Cold Spring Harbor Symp Quant Biol 42:755-772
Franke WW, Scheer U, Spring H, Trendelenburg MF, Zentgraf H (1979) In: Busch $H$ (ed) The cell nucleus, vol 7, part D. Academic Press, New York San Francisco London, p 49-95

Gall JG, Rochaix J-D (1974) Proc Natl Acad Sci USA 71: 1819-1823

Griffith JD (1975) Science 187: 1202-1203

Griffith JD, Christiansen G (1978) Cold Spring Harbor Symp Quant Biol 42:215-226

Hewish DR, Burgoyne LA (1973) Biochem Biophys Res Commun 52:504-510

Hozier J, Renz M, Nehls P (1977) Chromosoma 62:301-317

Kedinger C, Brison O, Perrin F, Wilhelm J (1978) $J$ Virol 26:364-379

Keller W, Müller U, Eicken I, Wendel I, Zentgraf H (1978) Cold Spring Harbor Symp Quant Biol 42:227-243

Kiryanov GJ, Manamshjan TA, Polyakov VYu, Fais D, Chentsov JuS (1976) FEBS Lett 67: 323-327

Kornberg RD (1974) Science 184:868-871

Matsuguchi M, Puvion-Dutilleul F, Moyne G (1979) J Gen Virol 42:443-456

Meyer GF, Renz M (1979) Chromosoma 75: 177-184

Miller OL, Hodge DL (1975) J Cell Biol 67:284 a

Morris NR (1976) Cell 9:627-632

Müller U, Zentgraf H, Eicken I, Keller W (1978) Science 201: 406-415

Müller U, Schröder CH, Zentgraf H, Franke WW (1980) Eur J Cell Biol, in press

Olins AL, Olins DE (1974) Science 183:330-332

Olins AL, Olins DE (1979) J Cell Biol 81:260-265

Olins AL, Olins DE, Zentgraf H, Franke WW (1980) J Cell Biol, in press

Paine PL, Moore LC, Horowitz SB (1975) Nature 254: 109-114

Pruitt SC, Grainger RM (1980) Chromosoma 78: 257-274

Rae PMM, Steele E (1978) Biosystems 10:37-53

Rattner JB, Hamkalo BA (1979) J Cell Biol 81: 453-457

Reeder RH, McKnight SL, Miller OL (1978) Cold Spring Harbor Symp Quant Biol 42:1174-1177

Renz M, Nehls P, Hozier H (1977) Proc Natl Acad Sci USA 74: 1879-1884

Riemann W, Muir C, Macgregor HC (1969) J Cell Sci 4:299-304

Riley D, Weintraub H (1979) Proc Natl Acad Sci USA 76:328-332

Scheer U, Zentgraf H (1978) Chromosoma 69: 243-254

Scheer U, Sommerville J, Müller U (1980) Exp Cell Res 129: 115-126

Spadafora C, Bellard M, Compton JL, Chambon P (1976) FEBS Lett 69:281-285

Strätling WH, Müller U, Zentgraf H (1978) Exp Cell Res 117:301-311 
Thoma F, Koller Th, Klug A (1979) J Cell Biol 83:403-427

Trendelenburg MF (1974) Chromosoma 48: 119-135

Trendelenburg MF, McKinnell RG (1979) Differentiation 15:73-95

Trendelenburg MF, Scheer U, Zentgraf H, Franke WW (1976) J Mol Biol 108:453-470

Wangh L, Ruiz-Carillo A, Allfrey VG (1972) Arch Biochem Biophys 150:44-56

Wyllie AH, Laskey RA, Finch J, Gurdon JB (1978) Dev Biol 64:178-188

Worcel A (1978) Cold Spring Harbor Symp Quant Biol 42:313-323
Zentgraf H, Falk H, Franke WW (1975) Cytobiologie 11:10-29

Zentgraf H, Keller W, Müller U (1978) Philos Trans R Soc Lond [Biol] 283:299-303

Zentgraf $H$, Trendelenburg MF, Spring H, Scheer U, Franke WW, Müller U, Drury KC, Rungger D (1979) Exp Cell Res 122:363-375

Zentgraf H, Müller U, Franke WW (1980a) Eur J Cell Biol 20:254-264

Zentgraf H, Müller U, Franke WW (1980 b) Eur J Cell Biol, in press 